\title{
Review on Knowledge and Knowledge Management from the Islamic Ethical Perspective
}

\author{
Nurul Izzah ${ }^{1}$, Liu Yao ${ }^{1}$, Noor Azlinna ${ }^{1}$, Damhuji $^{2}$ \\ ${ }^{1}$ Faculty of Technology, University Malaysia Pahang, Kuantan, Pahang \\ ${ }^{2}$ Faculty of Electrical \& Automation, TATIUC, Kemaman, Terengganu
}

\begin{abstract}
Knowledge movement has been increasingly regarded as a vital indicator of competitiveness. This paper aims to explore the origin of knowledge movement from the perspective of Islamic ethics. It overviews the concepts of knowledge and knowledge management and comprehends its implications. The main method is by interpreting the relevant citation from holy Qur'an. It highlights the Islamic conception of knowledge through understanding its nature in the reality of knowledge society. With regards to the Islamic conception of knowledge, the Qur'an invites human beings to read both the natural phenomena and the divine text (revelation). Generally speaking, knowledge management and classification are very much influenced by the way society conceptualizes and realizes knowledge. Eventually, knowledge management and classification guide man to the ways of knowledge utilization. Therefore, any success achieved by a person is an output of his/her knowledge understanding and knowledge growth within himself. In this status, human beings might be influenced by a certain situations, limitations and constrains internally or externally that lead him to persuade either body knowledge or the functional usage of knowledge in making his own individual
\end{abstract}

success in a form of user-centric based values. In this way, this paper is expected to extend the understanding of knowledge and provide a guide for Muslims to better manage knowledge with Islamic ethics.

Keywords: Knowledge; Knowledge management; Islamic; Competitiveness

\section{Introduction}

Globalization with developments from information communication technology (ICT) have exacerbated worldwide competition and been changing Islamic way of life. Consequently, more changes are to be witnessed in human-centric practices to comprehend and utilize knowledge to support innovations and enhance efficiencies.

Since Islam has long started knowledge management by converting Al Quran verses into the explicit Al Quran today, the notion of Islam as a "manner of submission" to God the Creator is a useful starting point to begin a discussion on the Islamic conceptualization of knowledge and knowledge management. According to the Al-Quran and Hadith, it is vital to face the challenges in the advent of knowledge economy, with sufficient understanding of "'ilm" knowledge within the Islamic fundamental principles of conducts and practices. 
This paper is attempting to review the concepts of knowledge and knowledge management and interpret its implications from the perspective of Islamic ethics. In this way, it is expected to extend the understanding of knowledge and provide a guide for Muslims to better manage knowledge with Islamic ethics.

\section{Knowledge and Islam}

Knowledge in nature is an old discipline which can be traced back to ancient Greeks (Kakabadse et al., 2003). The most accepted definition of knowledge is "justified true belief" (Audi, 1998). In this sense, knowledge is made by the mind (Bhatt, 2001). It is a product of human's reflection and experience (Roth, 2003). It emphasizes the idea of knowledge within the scope of the human factor.Quran al-Baqarah (30-33) reads:"And (remember) when your Lord said to the angels: "Verily, I am going to place (mankind) generations after generations on earth." They said: "Will You place therein those who will make mischief therein and shed blood, - while we glorify You with praises and thanks (Exalted be You above all that they associate with You as partners) and sanctify You." He (Allah) said:

"I know that which you do not know."(30) And He taught Adam all the names (of everything), then $\mathrm{He}$ showed them to the angels and said, "Tell Me the names of these if you are truthful."(31)

They (angels) said: "Glory be to You, we have no knowledge except what you have taught us. Verily, it is You, the AllKnower, the All-Wise."(32)

He said: "O Adam! Inform them of their names," and when he had informed them of their names, He said: "Did I not tell you that I know the Ghaib (unseen) in the heavens and the earth, and I know what you reveal and what you have been concealing?"(33)
Based on it, Islam is viewed as a religion of knowledge (Muhamadul, 2011), according to the Quran 96:1-5, Read! In the Name of your Lord, Who has created (all that exists) (1)

Has created man from a clot (a piece of thick coagulated blood) (2)

Read! And your Lord is the Most Generous, (3)

Who has taught (the writing) by the pen [the first person to write was Prophet Idris (Enoch)], (4)

Has taught man that which he knew not, (5).

Knowledge is regarded as God given to Mankind. It is to be used as reference or guidance for all human beings to elaborate an Islamic paradigm and intrinsically related to structuring their worldview towards all aspects of personal belief and social behavior. Prophet Muhammad (peace be upon him) once said "Verily, the men of knowledge are the inheritors of the prophets". In Islam, the value of a man lies in the value of his knowledge and it encourages human beings to acquire knowledge.

Thus as stated in the Quran, alBaqarah (239): And if you fear (an enemy), perform Salat (pray) on foot or riding. And when you are in safety, offer the Salat (prayer) in the manner He has taught you, which you knew not (before). (239)

The definition of knowledge is not restricted to only epistemological field but also includes ethical truthfulness and other dimensions of objectivities (Muhamadul, 2011). The Quran alBaqarah (29): He it is Who created for you all that is on earth. Then He Istawa (rose over) towards the heaven and made them seven heavens and $\mathrm{He}$ is the AllKnower of everything. (29)

Calls the divine trusteeship "amanah" as vicegerent "khilafah" and makes Man worthy of the exalted position as moral agents of God on earth. This is to say that 
for Man, the knowledge of what is materially useful is as essential as the knowledge of what is morally good. Both science and religion are needed in life to gain the power to conquest self as well as nature. In other words, what man needs is science structured by religion and what man requires is religion given intellectual content, wherever possible, by science as well as philosophy, without doing violence to its spiritual framework (Muhamadul, 2011).

So the personal reading as a mechanism of seeking knowledge should be performed in the Name of Lord, the Creator, the Most Generous who has taught Man. Thus, the Islamic request is not just to collect knowledge and information, but to direct man to organize, plan and manage properly the knowledge given to him. The Islamic concept of knowledge is illustrated in Figure1.
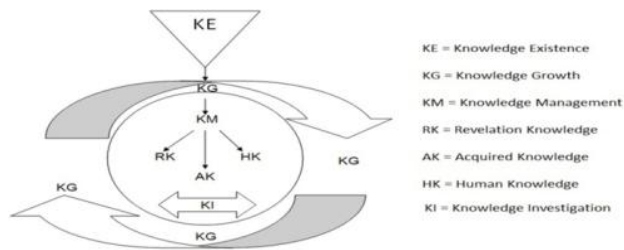

Fig. 1: The Islamic Conception of Knowledge.

Figure 1 describes that knowledge is stemmed from God, transferred to Mankind through various channels (i.e. observation, enlightenment, sense perception, reasoning, etc.) and further explored by man who knows it via knowledge management including acquisition, revelation, learning, etc. And during this investigation process, the knowledge continues growing in the person as well as in his surroundings since he will pass this knowledge to others. As a result, he as God's vicegerent on earth will be fully committed in investigating knowledge and developing its application as God created all those knowledge for him to be used and applied (Muhamadul, 2011). Consequently, a feasible model of knowledge management is on demand to be constructed in helping mankind to pursue knowledge especially under Islamic ethic perspective.

\section{Islamic knowledge management}

Scientifically, KM is composed of three elements: Body of Knowledge (BK), Methodology of Knowledge (MK) and Knowledge-based Users (KU). A more popular version of this three elements is: i) information, which are the pieces of facts and data that people convert into and apply as knowledge; ii) processes, with which people create, capture, store, organize and distribute knowledge; and iii) people (workers), who keep the knowledge and apply them. And these three components are indispensable to be considered when setting up a knowledge management program.

Islamic KM, however, has another additional element, that is the Knowledge Source (KS), since knowledge is considered co-existing with mankind. Figure 2 demonstrates these elements and their functional criteria. In the case, BK is not simply a collection of terminologies and abstract textual information without context, but with a sub-process of KM practices as shown by the four-headed arrows that occur when two or more individuals move closer towards each other exchanging knowledge. Therefore, Man's duty to search and develop that knowledge is according to their needs, urgencies and suitability. 


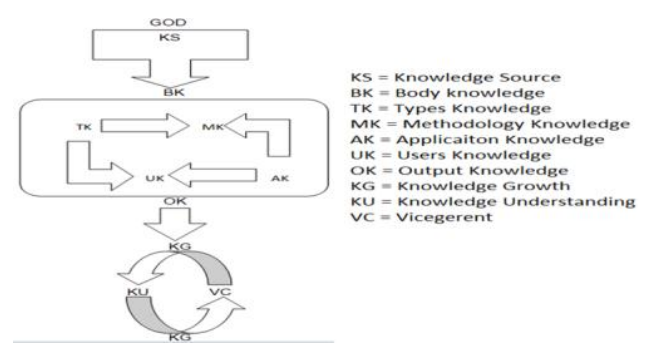

Fig. 2: the Functional Criteria of Islamic Knowledge Management.

The latent hypothesis here is when human beings are able to manage knowledge for themselves as structured by IKM, they will be able to recognize the greatness of Allah, the Creator of the universe (Muhamadul, 2011), which is based on Quran, az-Zumar (38):

And verily, if you ask them: "Who created the heavens and the earth?" Surely, they will say: "Allah (has created them)." Say: "Tell me then, the things that you invoke besides Allah, if Allah intended some harm for me, could they remove $\mathrm{His}$ harm, or if $\mathrm{He}$ (Allah) intended some mercy for me, could they withhold His Mercy?" Say: "Sufficient for me is Allah; in Him those who trust (i.e. believers) must put their trust."(38) and al-Fussilat (53):

We will show them Our Signs in the universe, and in their own selves, until it becomes manifest to them that this (the Qur'an) is the truth. Is it not sufficient in regard to your Lord that $\mathrm{He}$ is a Witness over all things?(53)

The output of this process is an effective user of knowledge as what God's vicegerent on earth is supposed to be, to practically apply knowledge to enhance the effectiveness of productivities and achievements. However, as human being, he might be influenced by a certain situation and constrain that lead him to manipulate either (BK) or (MK) or even (UK) in making his own success.

\section{Main Policies in the Islamic Knowledge Management}

Knowledge Management techniques can be used as tools to store, retrieve, disseminate and manage information related to user needs. Although taken from Western ideas, KM can be also used in Islam as long as it does not conflict with Shariah. For instance, Nonaka and Takeuchi (1995) discussed the first key factor of success for an organization which is to gain greater knowledge, especially in BK and TK. The second one is to be able to transform tacit knowledge into explicit knowledge in which the knowledge becomes useable (UK) and functional $(\mathrm{OK})$ within managerial activities. However, the Islamic organization's Knowledge Management must be based on four main policies.

- Seeking to please Allah and AlFalah as the goal

Goal of a Muslim in all cases is to seek the pleasure of Allah. Al-Falah means that success is not limited to the time dimension; it is success of the living world and the hereafter. When the Muslims or people are capable of doing good deeds throughout his life, he has managed to beat his heart from doing evil deeds. Hereafter in effect, the accumulated reward of good deeds is that he will enter heaven. Allah SWT says in at-Taubah (72-73):

Allah has promised to the believers -men and women, - Gardens under which rivers flow to dwell therein forever, and beautiful mansions in Gardens of 'Adn (EdenParadise). But the greatest bliss is the Good Pleasure of Allah. That is the supreme success.(72)

Prophet (Muhammad SAW) Strive hard against the disbelievers and the hypocrites, and be harsh against them, their abode is Hell, - and worst indeed is that destination.(73) 
- Implementing the 'Maaruf' and preventing the 'Mungkar'

Management efforts undertaken should ensure that the principles of implementing 'Maaruf' and preventing 'Mungkar' are done simultaneously. Maaruf means the good i.e. the belief and ahkam shariah of Islam such as salah, fasting, hajj, trust and etc. Mungkar means the evil things which are clearly haram, e.g. lying, slander, cheating, backbiting and etc.

Islam does not recognize two cases: i) implementing 'maaruf' without impeding 'Mungkar', e.g. employers ask employees to help one another to each other (maaruf), but the employer does not prevent or advise the independent association between male and female employees (mungkar); ii) preventing 'Mungkar' without performing 'maaruf', e.g. employer prohibits its employees from accepting or giving bribes, but the employer does not pay zakat on behalf of the company. Allah SWT says in alMaidah (2):

.....Help you one another in Al-Birr and At-Taqwa (virtue, righteousness and piety); but do not help one another in sin and transgression. And fear Allah. Verily, Allah is Severe in punishment.(2)

- Shariah as a source of knowledge and values

Every time that something is done from the smallest up to a mighty are subject to the law of the five, they are obligatory (haram), forbidden (makruh), disapproved (makruh), circumcision (sunnah) and optional (mubah). Otherwise, to do what is unlawful will invalidate the concept of work as worship (ibadah). The concept of work as worship (ibadah) is that doing every act must be intent only because of Allah. Shariah in simple words is the things to do were told or ordained by Allah, as were written in the al-Quran; and the Shariah cannot be increased or decreased. For example, usury is illegal; the sale and purchase is a circumcision (sunnah); prayer, fasting are obligatory for every Muslim, etc. Shariah must be the guide of implementing management as it is a source of knowledge and also the value of a Muslim. Allah SWT says in al-Maidah (16):

Wherewith Allah guides all those who seek His Good Pleasure to ways of peace, and $\mathrm{He}$ brings them out of darkness by His Will unto light and guides them to a Straight Way (Islamic Monotheism).(16)

- Human as caliph (Khalifah)

God's decision, or mandate, to make humans His successors, caliphs, on Earth is a great honor to them, but it is a grave responsibility at the same time. Human as Allah praised to Him, has the ability to learn, to accumulate knowledge, to process that knowledge, to make rules and laws on the basis of their knowledge, and to make use of what they have learned. Human also has tendency to construct as God's trust in His human creation to be His representatives on Earth to be creative in continuously improving their conditions on Earth, reaching the stage of civilization. So Man (human) is responsible for managing the world in terms of expansion and prosperity of natural resources. However, human also has freedom of choice as God's trust in His human creation to be His representatives on Earth; he is capable to choose between right and wrong and between obedience or disobedience. Thus, this concept is to invite or remind people to realize their role in managing their careers. The office or position is a trust from God but not to be proud of. Allah SWT says in adDzariyat (56): And I (Allah) created not the jinns and humans except they should worship Me (Alone).(56) 


\section{Conclusion}

To conclude, knowledge management and classification are very much influenced by the way society conceptualizes and realizes knowledge (Nonaka and Takeuchi, 1995). Eventually, knowledge management and classification guide man to the ways of knowledge utilization. Therefore, any success achieved by a person is an output of his/her knowledge understanding and knowledge growth within himself [Polanyi, 1966. In this status, human beings might be influenced by a certain situations, limitations and constrains internally or externally that lead him to persuade either body knowledge or the functional usage of knowledge in making his own individual success in a form of user-centric based values (Muhamadul, 2011). Therefore, this paper attempted to extend the understanding of knowledge and provide a guide for Muslims to better manage knowledge with Islamic ethics.

\section{References}

[1]G. Bhatt, "Knowledge management in organizations: examining the interaction between technologies, techniques, and people", Journal of Knowledge Management, 5(1), pp. 68-75, 2001.

[2]I. Nonaka, and H. Takeuchi, "The Knowledge Creating Company", New York: Oxford University Press, 1995.

[3]M. Bakir Yaakub, "Knowledge Management from Islamic Perspective", America. Journal of Economics and Business Administration, 3(2), pp. 14-24, 2011.

[4]N. Kakabadse, K. Andrew Kakabadse and Alexander Kouzmin, "Reviewing the knowledge management literature: towards a taxonomy", Journal of Knowledge Management, 7(4), pp. 75-91, 2003.
[5]Polanyi, “The Tacit Dimension", London, Routledge, University of Chicago Press, 1966.

[6]R. Audi, "Epistemology. A contemporary introduction to the theory of knowledge", London and New York: Routledge, 1998.

[7]Th. Roth-Berghofer, "Knowledge Maintenance of Case-Based Reasoning Systems - The SIAM Methodology", KI Kunstliche Intelligenz, 2003. 